\title{
DDS 抗がん剤の開発・製品化を期待して
}

\section{渡辺寬}

DDS 抗がん㶡の開発がはじまり， 臨床医がその計画に参画しほほ 25 年が経過しても, 未だ製品化された 薬剤が出現しない現状は何なのか？

DDS 抗がん剤は 30 年前から日本 独自の創意・工夫の研究成果があり ながら，ヒト癌に使える楽凨の製品 化は遅々として進まない, その原因 は多岐に渡るが, 基本となる要因に はつぎに記述する 3 要因が考えられ ます，最初の要因は癌細胞・組織へ の薬剤の移行の困難さが克服されて いないことであり, 第 2 は創薬企業 の開発研究者がヒト癌の現状を熟知 する臨床医と接触する機会が少ない こと, そして第 3 は企業のトップと なる人が夢と勇気を持ち合わせてい ないことです。これらの壁を突破す るには,これまでにない思い切った 発想の転換が必要でしょう。この機 会に私が 25 年前にDDS抗がん剂 を試作経験した貧弱な体験を踏まえ て, DDS 抗がん風の開発・製品化を 期待して私見を述べさせて頂きます.

研究者は日進月歩に出現する新し い癌情報に過敏になり, 細部にこだ わり, 発想当初の構想を見失ってし まう傾向が見られます。もちろん， 新しく発見された現象にすばやく即 応することも大切ではあるが, 癌に 関する既存の実態・現象を忘れては いないでしょうか，多くの癌專門医
は抗がん阂の癌細胞・組織への移行 は“血液を介して”という常識をもっ ておられることはいうまでもありま せん、この常識をDDS 抗がん剂に も当てはめ, 所謂 “Target” の機能 を製剈そのもにもたせる努力をされ ています。そこで勝手な提案をさせ て頂きますと, “Target”の視点を変 えてDDS 抗がん剂を癌細胞が菎密 に存在する場所(局所)に設置する，

“Targetする”考え方に変えてみる ことです，癌の外科療法後に微小転 移および手術操作による散布癌細胞 の存在を外科医は熟知しています. すなわち “Targeting place”を視野 に入れたDDS 抗がん剤の開発をめ さしてみることです.

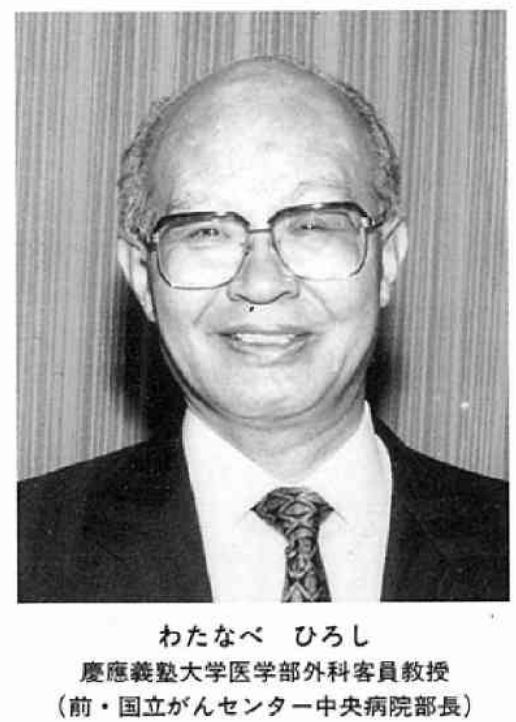

私は 20 年前, 術野に設置する植込 み型 DDS 抗がん㓮を開発・試作し, 臨床にてかなりの成果を得ました。 しかし多くのご高名な薬学者に “biodegradabilityでない薬剤は薬 剂ではない”と一蹴され, 異端者扱 いされ，企業側も製品化に踏み切る 勇気がなく逃げられてしまいまし た. 一般的には non biodegradable 製剤は生体内に異物として残ること を㲣念しますが, 生態系に与える影 響はすくないと考えます。事実, 手 術には縫合系, 止血クリップ, 人工 弁, 人工血管などを使用しています。

医学者が刻々生じる新しい科学現 象に即対応する新鮮な感受性を持ち 合わせることは重要であります。し かし新しい現象を充分自分のものに してから現在進行中の自己の研究に 応用する余裕をもち，さらにこれま で築き上げた既存の現象を忘れず研 究をつづけることも大切なことと思 います。

以上きわめて非常識的なことばか りを述べさして頂きましたが，大き な発想の転換なくしてDDS 抗がん 剤の開発・製品化の突破口は見つか らないと考え，あえて辛口な提案を させて頂きました，最後にDDS学 会会員の皆々様の開発に向けての努 力に期待します. 